\title{
DINHEIRO NÃO É PROBLEMA!
}

| POR ALINE LILIAN DOS SANTOS
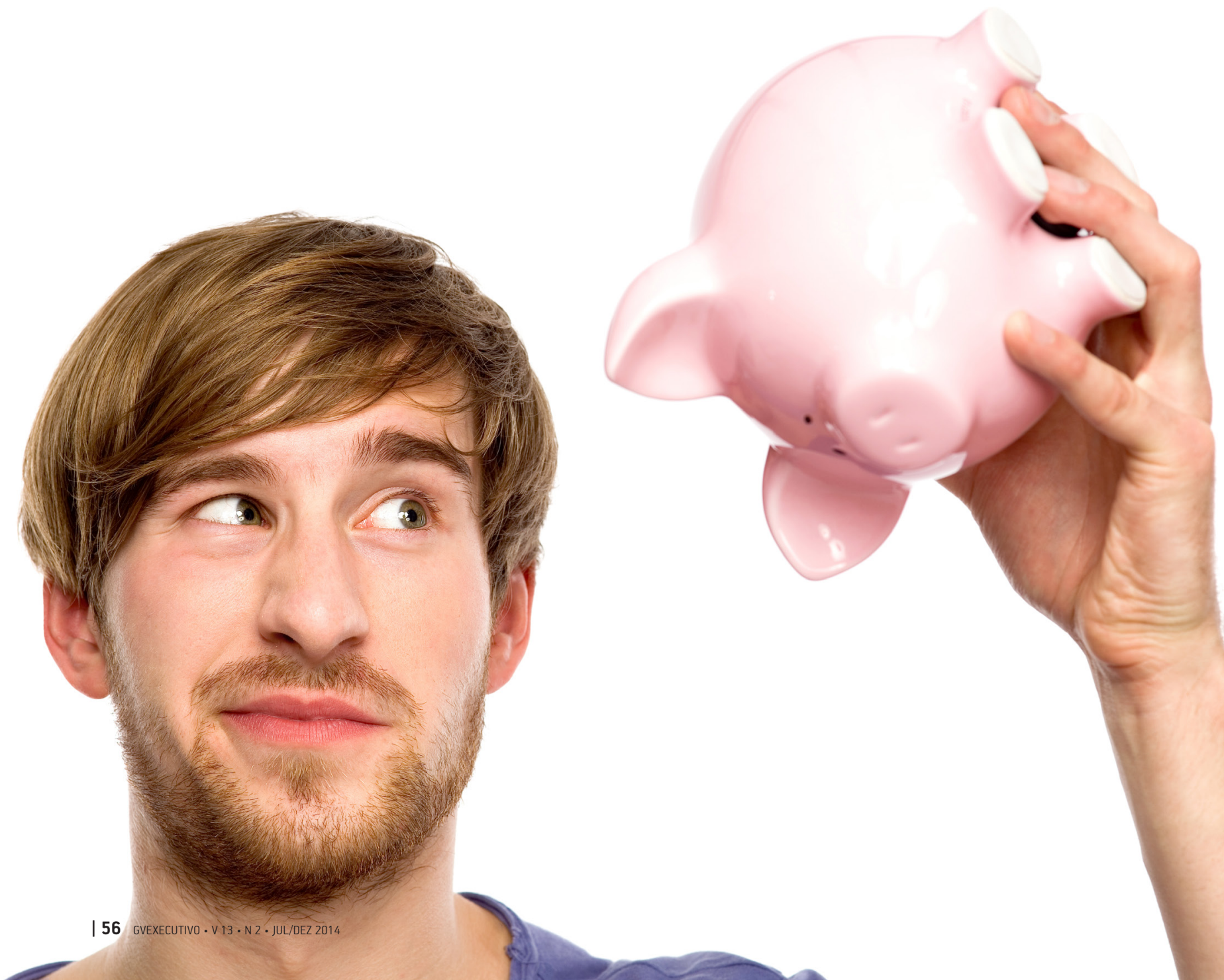


\section{O FUNDO DE BOLSAS DA FGV-EAESP JÁ BENEFICIOU MAIS DE 21.500 ALUNOS, FINANCIANDO OS ESTUDOS DE QUEM TEM DIFICULDADES ECONÔMICAS}

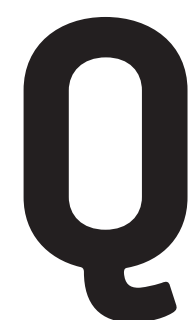

uando o aluno tem interesse e comprometimento, a falta de recursos financeiros não é uma barreira para ele cursar a graduação em Administração

Pública ou de Empresas na FGV-EAESP. Para que isso seja possível, a Escola mantém o Fundo de Bolsas. Criado em 1965, o programa foi pioneiro na concessão de crédito educativo no Brasil.

A proposta é que o aluno aprovado no vestibular consiga realizar o curso, independentemente da sua situação financeira. Hoje, cerca de $17 \%$ dos estudantes de graduação são atendidos pelo programa.

"É importante que aqueles que estudaram em colégio público ou foram bolsistas em instituições privadas, por exemplo, tenham condições de fazer o curso. Se conseguiram chegar até aqui, se passaram no vestibular, têm o seu mérito! Ninguém deve deixar de se graduar na Escola devido à sua condição econômica", explica o professor Arthur Ridolfo, presidente da Comissão responsável pelo programa.

\section{COMO FUNCIONA}

Atualmente, na FGV-EAESP, existem dois tipos de bolsa. A bolsa não restituível é conquistada por mérito, caso o aluno fique entre os 10 primeiros colocados no vestibular de Administração de Empresas ou entre os 5 no de Administração Pública, ou por necessidade econômica. Já a

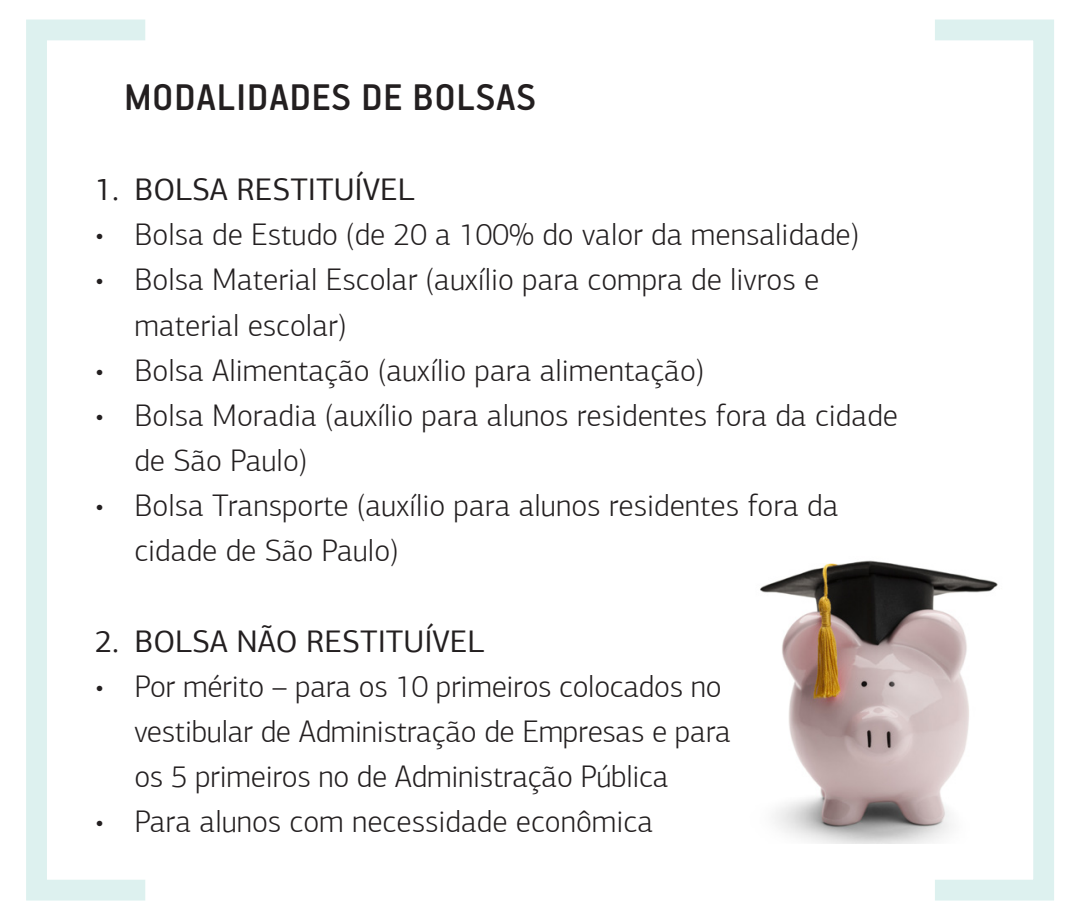

bolsa restituível permite ao estudante financiar o valor do curso para ressarcir a instituição depois de formado. Dentro dessa categoria também são oferecidos auxílio moradia, alimentação, transporte e material escolar.

As bolsas restituíveis, sobre as quais não são cobrados juros, partem do princípio de que o aluno concluirá a faculdade no período de quatro anos. Assim, a FGV-EAESP concede um ano de carência para ele se adaptar ao mercado de trabalho, e o pagamento do financiamento, corrigido pelo IGP-M da FGV, inicia-se a partir do quinto ano do ingresso do estudante na Escola.

\section{PARCEIROS}

O Fundo de Bolsas é constituído com a colaboração de empresas e pessoas físicas - entre elas, vários ex-alunos - além, naturalmente, do ressarcimento dos ex-bolsistas. "Qualquer pessoa pode colaborar", reforça o professor Arthur.

A solicitação de bolsa é semestral e pode ser efetuada pelo aluno no ato da matrícula ou durante o curso. Para informações adicionais, consulte a página do Fundo de Bolsas: eaesp.fgvsp.br/aluno/fundo-bolsas$\mathrm{GV}$ ou entre em contato pelo telefone (11) 3799-7786.

ALINE LILIAN DOS SANTOS > Jornalista da GV-executivo > aline.lilian@fgv.br 